\title{
PENINGKATAN KOMPETENSI PENGELOLAAN LABORATORIUM MELALUI PELATIHAN TERSTRUKTUR BAGI KEPALA LABORATORIUM DI SMP KECAMATAN TERAS PADA SEMESTER 2 TAHUN 2016/2017
}

\author{
Danto Kris Suwarno \\ Pengawas SMP Dinas Pendidikan dan Kebudayaan \\ Kabupaten Boyolali \\ E-mail: dantokrissuwarno1964@ gmail.com
}

\begin{abstract}
Abstrak
Penelitian ini bertujuan untuk 1) mengetahui peningkatan kompetensi pengelolaan laboratorium melalui pelatihan terstruktur dengan teknik saling berkunjung bagi kepala laboratorium di SMP Kecamatan Teras pada semester 2 tahun pelajaran 2016/2017, 2) mengetahui peningkatan kompetensi kepala laboratorium di SMP Kecamatan Teras dalam mengelola laboratorium setelah melaksanakan pelatihan terstruktur dengan teknik saling berkunjung pada semester 2 tahun pelajaran 2016/2017, 3) mengetahui perubahan perilaku kepala laboratorium di SMP Kecamatan Teras dalam mengelola laboratorium setelah melaksanakan pelatihan terstruktur dengan teknik saling berkunjung pada semester 2 tahun pelajaran 2016/2017. Metode penelitian ini adalah metode penelitian tindakan sekolah dengan memberikan tindakan dalam 2 siklus. Subyek penelitian adalah kepala laboratorium di SMP Kecamatan Teras dengan sampel sejumlah 12 kepala laboratorium dari 3 SMP negeri dan swasta. Hasil penelitian tindakan sekolah ini menunjukkan bahwa terdapat: 1) peningkatan proses pelatihan untuk peningkatan kompetensi kepala laboratorium; 2) terdapat peningkatan kinerja sebesar 42,50(117,2\%) dari rerata nilai kinerja 36,25 menjadi 78,75 dan peningkatan pengelolaan laboratorium sebesar 43,50 (128,8\%) dari rerata nilai 33,75 menjadi 77,50; dan (3) perubahan perilaku positif kepala laboratorium dari kategori cukup menjadi cukup tinggi.
\end{abstract}

Kata Kunci: pelatihan terstruktur, penilaian kinerja kepala laboratorium, supervisi pengelolaan laboratorium, dan kunjungan laboratorium.

\begin{abstract}
This study aims to 1) find out the improvement of laboratory management competencies through structured training with techniques to visit each other for the head of the laboratory in Teras Sub-district Middle School in the second semester of the 2016/2017 school year. structured training with techniques of visiting each other in the second semester of the 2016/2017 school year, 3) knowing changes in behavior of the head of the laboratory in Teras District Middle School in managing the laboratory after conducting structured training with visiting techniques in the second semester of the 2016/2017 school year The method of this research is the method of school action research by giving action in 2 cycles. The research subjects were the head of the laboratory in Teras Sub-district Middle School with a sample of 12 laboratory heads from 3 public and private junior high schools. The results of this school action research show that there are: 1) improvement of the training process to improve the competence of the head of the laboratory; 2) there is an increase in performance of 42.50 (117.2\%) from the average performance value of 36.25 to 78.75 and an increase in laboratory management by 43.50 (128.8\%) from the average value of 33.75 to 77.50 ; and (3) changes in the positive behavior of the head of the laboratory from sufficient categories are quite high.
\end{abstract}

Keywords: structured training, assessment of laboratory head performance, laboratory management supervision, and laboratory visits.

\section{Info Artikel}

Diterima Februari 2019, disetujui Maret 2019, diterbitkan Juni 2019 


\section{PENDAHULUAN}

Pengelola laboratorium utamanya kepala laboratorium merupakan salah satu komponen tenaga kependidikan yang perlu ditingkatkan mutunya, karena kepala laboratorium memiliki peran cukup besar bagi peningkatan mutu pembelajaran di laboratorium sekolah. Pengelolaan laboratorium yang baik dan profesional akan memiliki sumbangan positif terhadap mutu pembelajaran yang mengembangkan pola kerja ilmiah siswa. Berdasarkan Permendiknas Nomor 26 Tahun 2008 tentang Standar Tenaga Laboratorium Sekolah/Madrasah disebutkan bahwa seorang kepala laboratorium harus memiliki empat kompetensi yang memadai yakni kompetensi kepribadian, kompetensi sosial, kompetensi manajerial, dan kompetensi professional.

Sementara dalam Permendiknas Nomor 19 Tahun 2007 tentang Standar Pengelolaan disebutkan bahwa Pengelolaan laboratorium dikembangkan sejalan dengan perkembangan ilmu pengetahuan dan teknologi serta dilengkapi dengan manual yang jelas sehingga tidak terjadi kekeliruan yang dapat menimbulkan kerusakan. Sedangkan dalam Buku Pedoman Penilaian Kinerja Kepala Laboratorium/Bengkel Sekolah/Madrasah (Kemendiknas, 2011:2) menyebutkan bahwa: Tugas pokok Kepala laboratorium/bengkel sekolah adalah melaksanakan tugas yang bersifat akademik dan manajerial pada satuan pendidikan yang meliputi penyusunan program kerja laboratorium/bengkel, pelaksanaan program, pembinaan terhadap teknisi dan laboran, penilaian kinerja teknisi dan laboran, evaluasi hasil pelaksanaan program laboratorium/bengkel.

Tuntutan normatif di atas ternyata tidak sejalan dengan kondisi di lapangan, masih terdapat kesenjangan yang cukup signifikan antara realita pengelolaan laboratorium dengan tuntutan normatif tersebut. Secara umum kondisi pengelolaan laboratorium di Kecamatan Teras masih di bawah standar pengelolaan laboratorium yang diharapkan. Data hasil supervisi kondisi awal pengelolaan laboratorium SMP di Kecamatan Teras tahun pelajaran 2016/2017 menunjukkan bahwa semua aspek pengelolaan laboratorium dalam kondisi kurang meliputi: (1) perencanaan; (2) pengorganisasian; (3) pengelolaan; (4) pengembangan dan inovasi; (5) pengelolaan lingkungan, K3 (Kesehatan dan Keselamatan Kerja) dan B3 (Bahan Berbahaya Beracun); (6) pemantauan; dan (7) Evaluasi dan pelaporan. Sementara berdasarkan hasil wawancara dengan siswa menunjukkan bahwa frekuensi praktikum di laboratorium menunjukkan bahwa tingkat 
pengelolaan laboratorium dan penggunaan laboratorium untuk praktik siswa relatif rendah. Penggunaan laboratorium kurang dari 4 kali setahun atau satu semester kurang dari 2 kali menunjukkan nilai benefit (manfaat) laboratorium yang rendah.

Rendahnya tingkat pengelolaan dan pemanfaatan laboratorium ini disebabkan setidaknya oleh empat hal: (1) belum optimalnya tugas dan fungsi kepala laboratorium sesuai tuntutan Permendiknas No. 26 Tahun 2008; (2) kesadaran, komitmen, dan motivasi guru yang rendah untuk menggunakan laboratium; (3) kondisi fisik ruangan, penataan alat dan bahan yang kurang representative untuk kegiatan praktik laborat; (4) Jumlah laboran/teknisi yang minim karena rata-rata sekolah baru memiliki 1 orang laboran/teknisi untuk 3 (tiga) laboratorium IPA.

Berdasarkan kondisi riil pengelolaan laboratorium dan kondisi ideal yang digariskan dalam permendiknas maupun buku penilaian kinerja kepala laboratorium di atas, maka dapat disimpulkan bahwa ada tiga masalah pokok kinerja kepala laboratorium kaitannya dengan pengelolaan laboratorium, yaitu: (1) masalah kurangnya pemahaman kepala laboratorium tentang kompetensi mengelola laboratorium utamanya kompetensi manajerial dan kompetensi profesional; 2) masalah rendahnya kompetensi kepala laboratorium melaksanakan tugas pokok dan fungsinya dalam mengelola laboratorium; dan 3) masalah masih rendahnya komitmen kepala laboratorium dalam mengelola laboratorium yang optimal, efektif dan efisien dalam mendukung kegiatan pembelajaran dan penelitian. Sedangkan masalah diluar kepala laboratorium yang memiliki efek cukup besar terhadap tingkat pengelolaan laboratorium antara lain: (1) masih rendahnya komitmen guru menggunakan laboratorium untuk pembelajaran; (2) masih kecilnya dukungan kebijakan sekolah utamanya pendanaan untuk pengelolaan laboratorium; (3) belum terpenuhinya laboran/teknisi untuk memenuhi tenaga laboratorium sesuai standar.

Berkaitan dengan masalah-masalah yang terkait dengan kepala laboratorium, peneliti melakukan penelitian tindakan sekolah sebagai upaya meningkatkan kompetensi kepala laboratorium dalam mengelola laboratorium dengan tindakan pelatihan terstruktur teknik saling berkunjung. Tindakan yang dilakukan oleh peneliti adalah pelatihan penguasaan kompetensi manajerial dan kompetensi professional kepala laboratorium sesuai Permendiknas Nomor 26 Tahun 2008 yang dilaksanakan secara terstruktur sesuai urutan pada lampiran permendiknas tersebut. Pelaksanaan tugas dan 
fungsi kepala laboratorium diwujudkan dalam bentuk praktek mengerjakan tugas dan fungsi kepala laboratorium, kegiatan berkunjung ke laboratorium sekolah lain, dan tugas terstruktur yang harus diselesaikan di rumah maupun di sekolah. Hasil dari praktek mengerjakan tugas dan fungsi kepala laboratorium digunakan dan diaplikasikan untuk meningkatkan pengelolaan laboratorium yang menjadi tanggung jawabnya. Tindakan ini dilakukan sebanyak dua siklus yakni: siklus satu dua kali pertemuan dengan melakukan proses pelatihan dalam bentuk diskusi kelompok, kegiatan berkunjung, dan tugas terstruktur. Siklus dua sebanyak dua kali pertemuan dengan melakukan proses pelatihan dalam bentuk diskusi berpasangan, kegiatan berkunjung, dan tugas terstruktur. Diharapkan, dengan penelitian tindakan sekolah ini, kompetensi kepala laboratorium dalam mengelola laboratorium dapat ditingkatkan.

\section{KAJIAN TEORI}

Definisi kompetensi menurut Garcia-Barbero (1998:167) adalah: kombinasi dari sikap, pengetahuan, dan keterampilan yang diperlukan untuk melaksanakan tugas profesional. Selanjutnya Dobson (2003: 8), memberikan defenisi kompetensi yaitu: A competency is defined in terms of what a person is required to do (performance), under what conditions it is to be done (conditions) and how well it is to be done (standards). Sejalan dengan pendapat di atas, Permendiknas Nomor 23 Tahun 2006 tentang Standar Kompetensi Lulusan, menyebutkan bahwa kompetensi adalah kemampuan berfikir, bersikap dan bertindak secara konsisten sebagai perwujudan dari pengetahuan, sikap, dan keterampilan yang dimiliki peserta didik (seseorang).

Lebih fokus, Peraturan Pemerintah Nomor 74 Tahun 2008 tentang Guru pada pasal 3 ayat (1) dinyatakan bahwa kompetensi adalah seperangkat pengetahuan, keterampilan, dan perilaku yang harus dimiliki, dihayati, dikuasai, dan diaktualisasikan oleh Guru dalam melaksanakan tugas keprofesionalan. Berdasarkan pendapat-pendapat tersebut, dapat disimpulkan bahwa kompetensi adalah seperangkat pengetahuan, keterampilan, dan perilaku yang dimiliki, dihayati, dikuasai dan diaktualisasikan dalam kebiasaan berpikir, bersikap, dan bertindak.

Kepala laboratorium adalah guru, laboran atau teknisi yang berkualifikasi dan berpengalaman minimal yang dipersyaratkan, serta telah bersertifikat dengan tugas pokok utama bidang manajerial dan akademik (profesional) meliputi perencanaan, 
pengorganisasian, pelaksanaan, pembinaan, penilaian, pemantauan, evaluasi, dan laporan. kompetensi kepala laboratorium adalah seperangkat pengetahuan, keterampilan, dan perilaku yang dimiliki, dihayati, dikuasai, dan diaktualisasikan dalam kebiasaan berpikir, bersikap, dan bertindak kepala laboratorium ketika melaksanakan tugas manajerial dan tugas keprofesionalannya.

Kompetensi yang harus dimiliki kepala laboratorium berdasarkan Permendiknas Nomor 26 Tahun 2008 tentang Standar Tenaga Laboratorium Sekolah/Madrasah meliputi 4 dimensi kompetensi yakni kompetensi kepribadian, kompetensi sosial, kompetensi manajerial, dan kompetensi profesional. Sedangkan kompetensi yang mengarah kepada kemampuan untuk mengelola laboratorium adalah kompetensi manajerial dan professional.

Prestasi kerja kepala laboratorium sekolah dalam menunaikan tugas pokoknya perlu mendapat penilaian untuk mengukur kompetensi kepala laboratorium dalam mengelola laboratorium sekaligus sebagai penghargaan atas prestasi pengelolaannya. Berdasarkan Pedoman Penilaian Kinerja Kepala Laboratorium Sekolah (Kemendikbud, 2011) penilaian kinerja didefinisikan sebagai rangkaian proses penilaian untuk menentukan derajat mutu kinerja terhadap target kegiatan kepala laboratorium dalam melaksanakan tugasnya atau pekerjaannya yang telah dicapai.

Berdasarkan Peraturan Menteri Pendayagunaan Aparatur Negara Nomor 21 Tahun 2010 sasaran penilaian kinerja kepala laboratorium meliputi: kompetensi kepribadian, sosial, manajerial, dan sosial, sedangkan dalam penelitian ini kompetensi yang digunakan untuk mengukur peningkatan kompetensi pengelolaan laboratorium adalah kompetensi utama pengelolaan yakni kompetensi manajerial dan kompetensi profesional. Permenpan Nomor 21 Tahun 2010 selanjutnya menjelaskan bahwa: (1) Kompetensi profesional yang dinilai meliputi: mengikuti perkembangan pemikiran tentang pemanfaatan kegiatan laboratorium sebagai wahana pendidikan, menerapkan hasil inovasi atau kajian laboratorium/bengkel, menyusun panduan/penuntun (manual) praktikum, merancang kegiatan laboratorium untuk pendidikan dan penelitian, melaksanakan kegiatan laboratorium untuk kepentingan pendidikan dan penelitian, mempublikasikan karya tulis ilmiah hasil kajian/inovasi, menetapkan ketentuan mengenai kesehatan dan keselamatan kerja, menerapkan ketentuan mengenai kesehatan 
dan keselamatan kerja, menerapkanprosedur penanganan bahan berbahaya dan beracun, memantau bahan berbahaya dan beracun, serta peralatan keselamatan kerja.

Selanjutnya (2) Kompetensi profesional yang dinilai meliputi: mengikuti perkembangan pemikirantentang pemanfaatan kegiatan laboratorium/bengkel sebagai wahana pendidikan, menerapkan hasil inovasi atau kajian laboratorium/bengkel, menyusun panduan/penuntun (manual) praktikum, merancang kegiatan laboratorium/bengkel untuk pendidikan dan penelitian, melaksanakan kegiatan laboratorium/bengkel untuk kepentingan pendidikan dan penelitian, mempublikasikan karya tulis ilmiah hasil kajian/inovasi, menetapkan ketentuan mengenai kesehatan dan keselamatan kerja, menerapkan ketentuan mengenai kesehatan dan keselamatan kerja, menerapkan prosedur penanganan bahan berbahaya dan beracun, memantau bahan berbahaya dan beracun, serta peralatan keselamatan kerja.

\section{HASIL DAN PEMBAHASAN}

Hasil penelitian tindakan sekolah ini diperoleh dari kondisi awal, siklus 1, dan siklus 2. Kondisi awal pengelolaan laboratorium diperoleh melalui hasil awal penilaian kinerja kepala laboratorium, hasil awal supervisi pengelolaan laboratorium, hasil dokumentasi foto kondisi awal laboratorium, dan hasil wawancara pengelolaan laboratorium sebelum dilakukan tindakan penelitian. Hasil tindakan penelitian pada siklus 1 dan siklus 2 berupa perubahan hasil penilaian kinerja kepala laboratorium, perubahan hasil supervisi pengelolaan laboratorium, dan perubahan hasil dokumentasi, kondisi fisik laboratorium, sedangkan hasil perubahan perilaku diperoleh melalui deskripsi perilakuekologis, wawancara, dan dokumentasi foto. Hal yang dibahas berupa proses pelatihan terstruktur dan kunjungan laboratorium, peningkatan kinerja kepala laboratorium, peningkatan hasil supervisi pengelolaan laboratorium, peningkatan kondisi fisik laboratorium, dan perubahan perilaku kepala laboratorium selama tindakan dan melaksanakan tugas terstruktur untuk pembenahan laboratorium.

Penilaian kinerja kepala laboratorium pada kondisi awal dilakukan di masingmasing laboratorium sekolah untuk mengetahui tingkat kinerja awal kepala laboratorium dengan melihat kondisi riil pengelolaan laboratorium yang menjadi tangung jawabnya selama ini. Hasil penilaian kinerja kepala laboratorium dalam mengelola laboratorium meliputi dimensi kompetensi manajerial yang terdiri dari: (1) 
pengorganisasian guru, laboran, dan teknisi; (2) pengelolaan program dan administrasi; (3) Pemantauan dan Evaluasi ; dan dimensi kompetensi profesional profesional yang terdiri dari: (1) Pengembangan dan Inovasi; (2) Lingkungan, K3, dan B3; (3) pada kondisi awal adalah sebagai berikut:

Tabel 1 .

Hasil Penilaian Kinerja Kepala Laboratorium pada Kondisi Awal

\begin{tabular}{|c|c|c|c|c|c|}
\hline Kategori & Interval & Median & Frek & Med x Frek & Keterangan \\
\hline Baik sekali & $86-100$ & 92,5 & 0 & 0 & \\
\hline & & & & & Mean $=\underline{405}=33,75$ \\
\hline Baik & $71-85$ & 77,5 & 0 & 0 & $\overline{12}$ \\
\hline Cukup & $55-70$ & 62,5 & 0 & 0 & Modus $=(25-40)$ \\
\hline Kurang & $41-55$ & 47,5 & 1 & 47,5 & Median $=33,00$ \\
\hline Kurang sekali & $25-40$ & 32,5 & 11 & 357,5 & \\
\hline Jumlah & & & 12 & 405 & \\
\hline
\end{tabular}

Hasil supervisi pengelolaan laboratorium pada kondisi awal ternyata sejalan dengan hasil penilaian kinerja kepala laboratorium, Secara keseluruhan hasil supervisi laboratorium menunjukkan hampir di semua aspek pengelolaan laboratorium kondisinnya lemah yakni aspek perencanaan, pengorganisasian, pengelolaan, pengembangan inovasi, pengelolaan lingkungan K3/B3, monitoring, evaluasi, dan laporan.

Tabel 2.

Hasil Supervisi Pengelolaan Laboratorium pada Kondisi Awal

\begin{tabular}{lccccl}
\hline Kategori & Interval & Median & Frek & Med x Frek & Keterangan \\
\hline Baik sekali & $86-100$ & 92,5 & 0 & 0 & \multirow{2}{*}{ Mean $=\underline{435}=36,25$} \\
Baik & $71-85$ & 77,5 & 0 & 0 & \\
Cukup & $55-70$ & 62,5 & 0 & 0 & Modus $=(25-40)$ \\
Kurang & $41-55$ & 47,5 & 3 & 142,5 & Median $=36,50$ \\
Krng sekali & $25-40$ & 32,5 & 9 & 292,5 & Ketuntasan $=\underline{0 x} 100 \%=0 \%(\geq 70)$ \\
\cline { 1 - 4 } Jumlah & & & 12 & 435 &
\end{tabular}

Berdasarkan Tabel 2. diketahui bahwa pada kondisi awal nilai rata-rata (mean) hasil supervisi pengelolaan laboratorium sebesar 33,75 nilai tengah (median) sebesar 33, dan nilai yang sering muncul (modus) berada pada interval (25-40). Hal ini menunjukkan bahwa rata-rata pengelolaan laboratorium oleh kepala laboratorium sangat kurang atau kurang sekali. Pada Tabel 1, diketahui nilai rata-rata (mean) sebesar 36,25, 
nilai tengah (median) sebesar 36,50, dan nilai yang sering muncul (modus) pada interval (25-40). Hal ini menunjukkan bahwa dengan data ukuran tendensi sentral (mean, modus median) seperti tersebut di atas, kinerja rata-rata kepala laboratorium masih dalam kategori kurang sekali dan masih jauh dari standar ketuntasan yang ditetapkan dalam penelitian ini, yaitu sebesar 70. Berdasarkan data-data pada kondisi awal ini dapat disimpulkan bahwa kinerja kepala laboratorium dalam mengelola laboratorium masih kurang, sehingga perlu ditingkatkan.

Kegiatan siklus 1 merupakan tindakan lanjutan setelah melihat data kondisi riil yang diperoleh pada kondisi awal. Kegiatan pelatihan siklus 1 dilaksanakan sebanyak 2 (dua) kali pertemuan dengan menerapkan pelatihan terstruktur saling berkunjung dan diskusi kelompok kepala laboratorium sejenis. Materi pertemuan pertama: (1) pengenalan kinerja kepala laboratorium; dan (2) perencanaan laboratorium; sedangkan materi pertemuan kedua: (3) pengorganisasian guru, teknisi, laboran; dan (4) pengelolaan program dan administrasi.perencanaan.

Pemaparan hasil penelitian siklus 1 diawali dengan memaparkan proses pelatihan terstruktur yang diakhiri dengan kunjungan laboratorium dan tugas terstruktur peningkatan pengelolaan laboratorium di sekolah berdasarkan hasil instrumen deskripsi perilaku ekologis, dan hasil observasi. Pemaparan selanjutnya mengenai peningkatan kinerja kepala laboratorium melalui hasil penilaian kinerja kepala laboratorium dan hasil supervisi pengelolaan laboratorium setelah pelatihan terstruktur, kunjungan laboratorium, dan melaksanakan tugas terstruktur. Sedangkan penjelasan mengenai perubahan perilaku berupa deskripsi empat karakter kepala laboratorium, yaitu keaktifan, kedisiplinan, kepercayaan diri, dan kemampuan bekerja sama dan berbagi dikemukakan kemudian.

Kegiatan siklus 2 merupakan tindakan lanjutan setelah melihat data kondisi riil yang diperoleh pada siklus 1. Kegiatan pelatihan siklus 2 dilaksanakan sebanyak 2 (dua) kali pertemuan dengan menerapkan pelatihan terstruktur saling berkunjung dan diskusi berpasangan kepala laboratorium sejenis. Perubahan diskusi kelompok menjadi diskusi berpasangan didasarkan pada hasil refleksi perubahan perilaku dengan tujuan agar keaktifan, kerjasama dan berbagi, kedisiplinan, dan kepercayaan diri lebih meningkat. Materi pertemuan pertama: (1) pengelolaan, pemantauan, dan evaluasi, sedangkan 
materi pertemuan kedua: (2) pengembangan dan inovasi; dan (3) pengelolaan lingkungan, Kesehatan Keselamatan Kerja (K3), Bahan Berbahaya beracun (B3).

Pemaparan hasil penelitian siklus 2 diawali dengan memaparkan proses pelatihan terstruktur yang diakhiri dengan kunjungan laboratorium dan tugas terstruktur peningkatan pengelolaan laboratorium di sekolah. Pemaparan selanjutnya mengenai peningkatan kinerja kepala laboratorium melalui hasil penilaian kinerja kepala laboratorium dan hasil supervisi pengelolaan laboratorium setelah pelatihan terstruktur, kunjungan laboratorium, dan melaksanakan tugas terstruktur. Sedangkan penjelasan mengenai perubahan perilaku berupa deskripsi empat karakter kepala laboratorium, yaitu keaktifan, kedisiplinan, kepercayaan diri, dan kemampuan bekerja sama dan berbagi dikemukakan kemudian berdasarkan hasil deskripsi perubahan ekologis dan hasil dokumentasi. Peningkatan proses pelatihan terstruktur dengan kunjungan laboratorium dan tugas terstruktur dipaparkan peningkatan proses pelatihan terstruktur dari siklus1 ke siklus 2, hal ini disebabkan karena pada kondisi awal tidak ada proses pelatihan. Berdasarkan hasil observasi proses pelatihan terstruktur, disajikan hasil observasi siklus 1 dan siklus 2 dan peningkatan proses pelatihan yang disajikan pada tabel 3.

Tabel 3.

Rekapitulasi Data Peningkatan Proses Pelatihan Terstruktur

\begin{tabular}{cccccccccc}
\hline \multirow{2}{*}{ No } & Aspek & \multicolumn{2}{c}{ Siklus 1 } & \multicolumn{2}{c}{ Siklus 2 } & \multicolumn{2}{c}{ Peningkatan } & \multicolumn{2}{c}{ \% Peningkatan } \\
\cline { 3 - 9 } & Observasi & Psrta & Pnlti & Psrta & Pnlti & Psrta & Pnlti & Psrta & Pnlti \\
\hline 1 & Pendahuluan & 2,70 & 2,80 & 2,90 & 3,00 & 0,20 & 0,20 & $7,4 \%$ & $7,1 \%$ \\
2 & Kegiatan Inti & 2,34 & 2,78 & 2,73 & 2,93 & 0,39 & 0,15 & $16,6 \%$ & $5.4 \%$ \\
3 & Penutup & 2,50 & 2,50 & 2,87 & 3,00 & 0,37 & 0,50 & $14,8 \%$ & $20 \%$ \\
\hline & Rata-rata & 2,45 & 2,69 & 2,79 & 2,97 & 0,34 & 0,28 & $13,6 \%$ & $10,4 \%$ \\
\hline
\end{tabular}

Proses pelatihan terstruktur siklus 1 yang dikembangkan dengan pendekatan pola eksplorasi, elaborasi, dan konfirmasi, berdampak positif terhadap peningkatan aktivitas peserta maupun peneliti dalam kegiatan inti pelatihan terstruktur dengan pola diskusi kelompok kepala laboratorium sejenis. Melalui observasi proses, kegiatan pelatihan terstruktur terlihat cukup aktif dan lebih bervariatif dilakukan dalam tiga variasi kegiatan. Rata-rata keterlibatan peserta dalam proses pelatihan memang berada pada kategori sedang $(2,45)$ namun jika dilihat lebih rinci kegiatan pendahuluan dan penutup keterlibatan peserta pelatihan pada kategori tinggi (2,70 dan 2,50), sedangkan pada kegiatan inti dalam kondisi sedang $(2,34)$. Kegiatan peneliti pada tiga tahap pelatihan 
pada kategori tinggi grade bawah karena nilai rata-rata keterlibatan dalam proses masih berada pada skor 2,69. Kelemahan yang bisa diidentifikasikan pada siklus 1 adalah :

1. Untuk peserta, pada pendahuluan kurang optimal perhatiannya terhadap tema, tujuan yang akan dibahas dan tugas yang akan dilaksanakan, sedangkan pada kegiatan inti kurang antusias bertanya, menggunakan media, dan bersemangat untuk paparan, dan pada penutup belum optimal keikutsertaan mengambil kesimpulan, dan tugas terstruktur.

2. Untuk peneliti, pada pendahuluan belum optimal melakukan apersepsi, motivasi, dan menjelaskan tugas, sedangkan pada kegiatan inti belum optimal melakukan pemantauan kegiatan elaborasi dan semangat menjawab pertanyaan peserta, dan pada penutup belum optimal dalam melakukan postes dan pemberian tugas terstruktur.

Proses pelatihan terstruktur pada siklus 2 dilaksanakan berdasarkan hasil refleksi siklus 1 yakni meliputi kelemahan peserta dan peneliti pada tahap pendahuluan, kegiatan inti, dan penutup yang sudah dikemukakan di atas. Untuk meningkatkan keterlibatan peserta dalam proses pelatihan terstruktur siklus 2 diambil langkah untuk mengubah pola diskusi kelompok menjadi diskusi berpasangan, sedangkan bagi peneliti berusaha memperbaiki langkah pelatihan yang belum optimal dan meningkatkan langkah pelatihan yang sudah memenuhi standar eksplorasi, elaborasi, dan konfirmasi.

Hasil observasi proses pelatihan terstruktur pada siklus 2 dapat disampaikan pembahasan sebagai berikut: Rata-rata peran serta peserta dalam proses pelatihan meningkat naik menjadi kategori tinggi $(2,79)$ hal ini didukung oleh keterlibatan siswa di semua tahapan pelatihan pada kategori tinggi pendahuluan $(2,90)$, kegiatan inti $(2,73)$ dan penutup $(2,87)$. Kegiatan peneliti pada tiga tahap pelatihan pada kategori tinggi karena skor rata-rata keterlibatan dalam proses meningkat menjadi tinggi hampir penuh $(2,97)$. Kelemahan teridentifikasi pada siklus 2 adalah:

1. Untuk peserta, pada kegiatan inti belum optimal menggunakan media yanng disediakan, belum optimal memanfaatkan waktu bertanya

2. Untuk peneliti, pada kegiatan inti belum aptimal menggunakan lingkungan, benda, administrasi riil untuk mendukung proses pelatihan.

Berdasarkan hasil observasi proses pelatihan pada siklus 1 dan siklus 2 terdapat peningkatan proses pelatihan terstruktur pada semua tahapan pelatihan, yaitu: 1) 
kegiatan pendahuluan mengalami peningkatan keterlibatan peserta dalam proses pelatihan sebesar $0,20(7,4 \%)$ dan peneliti sebesar $0,20(7,1 \%)$, kegiatan inti mengalami peningkatan keterlibatan peserta dalam proses pelatihan sebesar 0,39 (16,6\%) dan peneliti sebesar $0,15(5,4 \%)$, serta kegiatan penutup mengalami peningkatan keterlibatan peserta dalam proses pelatihan sebesar $0,37(14,8 \%)$ dan peneliti sebesar 0,50 (20\%). Hasil penelitian ini sesuai pendapat Mathis (2002) yang menyatakan: "Pelatihan adalah suatu proses dimana orang-orang akan terangsang lebih aktif melakukan sesuatu untuk mencapai kemampuan tertentu dan membantu mencapai tujuan organisasi”.

Kemudian dilihat dari hasil penilaian kinerja kepala laboratorium, dapat diketahui adanya peningkatan nilai rerata, nilai tertinggi, nilai terendah, dari kondisi awal, setelah tindakan siklus 1, dan pada akhir tindakan siklus 2. Pada saat kondisi awal, nilai rerata kinerja kepala laboratorium sebesar 36,25, kemudian meningkat menjadi 68,75 pada akhir tindakan siklus 1, dan meningkat lagi menjadi 78,75 pada akhir tindakan siklus 2 . Nilai rerata sebesar 78,75 menunjukkan bahwa indikator kinerja penelitian sebesar 70 terpenuhi artinya pelatihan dengan tugas terstruktur dan teknik saling berkunjung dapat meningkatkan kinerja kepala laboratorium dari semula kategori kurang sekali $(36,25)$ menjadi kategori baik $(78,75)$. Secara keseluruhan terdapat peningkatan yang cukup signifikan nilai rerata kepala laboratorium dari kondisi awal sampai akhir tindakan pada siklus 2 yakni sebesar 42,50 .

Peningkatan nilai rerata dari kondisi awal sampai akhir tindakan siklus 1 peningkatannya sebesar 32,50 (89,65\%), hal ini lebih dipengaruhi karena pada kondisi awal sebagian besar kepala laboratorium belum melakukan sebagian besar kegiatan yang harus dilakukan sesuai tuntutan standar tenaga laboratorium. Setelah diberikan pelatihan dengan tugas terstruktur dan berkunjung ke laboratorium rata-rata kepala laboratorium merasakan bahwa tupoksi kepala laboratorium tidak terlalu sulit untuk dilakukan, hanya volumenya yang banyak harus dibuat sehingga ketika tindakan siklus 1 dilaksanakan peningkatan nilai rerata kinerja kepala laboratorium cukup tinggi. Sedangkan pada tindakan siklus 2 pelatihan terstruktur dengan diskusi berpasangan dan kunjungan ke laboratorium dan mengerjakan tugas terstrukur pembenahan laboratorium kenaikan nilai rerata kinerja kepala laboratorium mengalami kenaikan sebesar 10,00 (14,54\% dari hasil nilai siklus 1 atau 27,58\% dari kondisi awal). 
Nilai tertinggi kepala laboratorium pada saat kondisi awal sebesar 41,00, kemudian meningkat menjadi 76,00 pada akhir tindakan siklus 1, dan meningkat lagi menjadi 86,00 pada akhir tindakan siklus 2. Secara keseluruhan terdapat peningkatan yang cukup signifikan nilai tertnggi hasil pelatihanterstruktur dari kondisi awal sampai akhir tindakan pada siklus 2 yakni sebesar 45,00. Relevan dengan kenaikan nilai rerata, kenaikan nilai terendah juga cukup tinggi. Pada kondisi awal nilai terendah knerja kepala laboratorium sebesar 27.00 kemudian meningkat cukup tinggi menjadi 61,00 pada akhir tindakan siklus 1, dan meningkat lagi menjadi 74.00 pada akhir tindakan siklus 2. Secara keseluruhan terdapat peningkatan yang cukup signifikan nilai terendah hasil pelaihan terstruktur dari kondisi awal sampai akhir tindakan pada siklus 2 yakni sebesar 47,00 .

Rentang nilai kinerja kepala laboratorium pada saat kondisi awal sebesar 14,00, kemudian naik menjadi 15,00 pada akhir tindakan siklus 1, dan menurun lagi menjadi 12,00 pada akhir tindakan siklus 2. Secara keseluruhan terdapat penurunan rentang nilai tertinggi dan terendah kinerja kepala laboratorium dari kondisi awal sampai akhir tindakan pada siklus 2 yakni sebesar 2,00. Kondisi rentang nilai yang semakin turun menunjukkan perbedaan kinerja kepala laboratorium semakin kecil. Perbandingan ketiga kondisi diatas dapat disajikan dalam Tabel 4 berikut ini.

Tabel 4

Perbandingan Nilai Kinerja Kepala Laboratorium pada

Kondisi Awal, Siklus 1, dan Siklus 2

\begin{tabular}{llcccl}
\hline No & Komponen & $\begin{array}{c}\text { Kondisi } \\
\text { Awal }\end{array}$ & $\begin{array}{c}\text { Siklus } \\
\mathbf{1}\end{array}$ & $\begin{array}{c}\text { Siklus } \\
\text { 1I }\end{array}$ & $\begin{array}{c}\text { Refleksi dari kondisi awal ke } \\
\text { kondisi akhir }\end{array}$ \\
\hline 1. & Nilai Rerata & 36,25 & 68,75 & 78,75 & $\begin{array}{l}\text { Terjadi peningkatan nilai rerata } \\
\text { sebesar 42,50 } \\
\text { Terjadi peningkatan nilai tertinggi } \\
\text { sebesar 45,00 }\end{array}$ \\
2. & $\begin{array}{l}\text { Nilai } \\
\text { Tertinggi }\end{array}$ & 41,00 & 76,00 & 86,00 & $\begin{array}{l}\text { Terjadi peningkatan nilai terendah } \\
\text { sebesar 47,00 } \\
\text { Terjadi penurunan ren tang nilai } \\
\text { 3. }\end{array}$ \\
$\begin{array}{l}\text { Nilai } \\
\text { Terendah } \\
\text { Rentang }\end{array}$ & 27,00 & 61,00 & 74,00 02,00 \\
\hline
\end{tabular}

Perbandingan nilai kondisi awal, siklus 1 dan siklus 2 dapat pula dideskripsikan dalam gambar 1. berikut ini. 


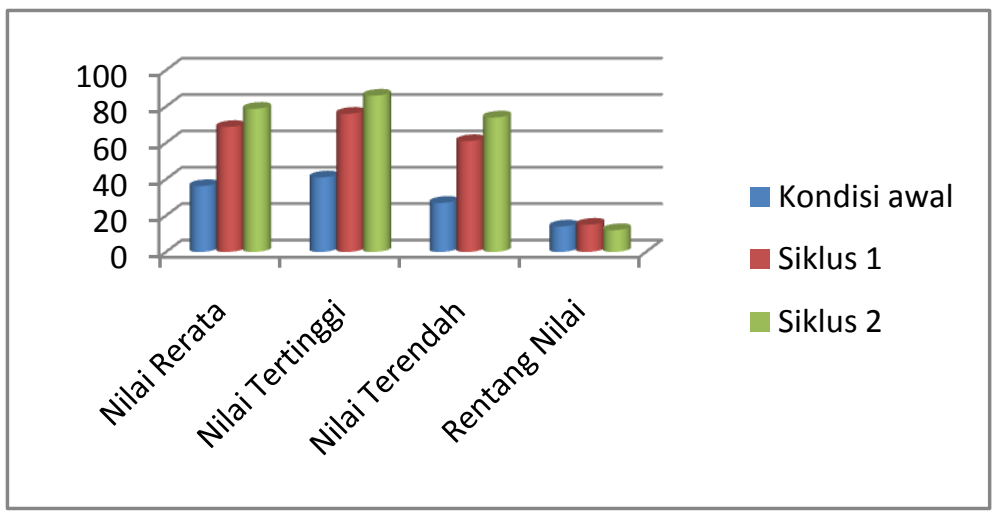

Gambar 1. Diagram Balok Perbandingan Kinerja Kepala Laboratorium

Dilihat dari hasil supervisi pengelolaan laboratorium, dapat diketahui adanya peningkatan nilai rerata, nilai tertinggi, nilai terendah, dari kondisi awal, setelah tindakan siklus 1, dan pada akhir tindakan siklus 2. Pada saat kondisi awal, nilai rerata supervisi pengelolaan laboratorium sebesar 37,25, kemudian meningkat menjadi 70,00 pada akhir tindakan siklus 1, dan meningkat lagi menjadi 77,50 pada akhir tindakan siklus 2. Nilai rerata pengelolaan laboratorium sebesar 77,50 menunjukkan bahwa indikator kinerja penelitian sebesar 70 terpenuhi artinya pelatihan dengan tugas terstruktur dan teknik saling berkunjung dapat meningkatkan pengelolaan laboratorium dari semula kategori kurang sekali $(33,75)$ menjadi kategori baik $(77,50)$. Secara keseluruhan terdapat peningkatan yang cukup signifikan nilai pengelolaan laboratorium dari kondisi awal sampai akhir tindakan pada siklus 2 yakni sebesar 43,75.

Peningkatan nilai rerata dari kondisi awal sampai akhir tindakan siklus 1 peningkatannya sebesar 36,25 (107,4\%), hal ini sejalan dengan hasil penilaian kinerja kepala laboratorium yakni lebih dipengaruhi karena pada kondisi awal sebagian besar kepala laboratorium belum melakukan sebagian besar kegiatan yang harus dilakukan sesuai tuntutan standar tenaga laboratorium. Setelah diberikan pelatihan dengan tugas terstruktur dan berkunjung ke laboratorium rata-rata kepala laboratorium merasakan bahwa tupoksi kepala laboratorium tidak terlalu sulit untuk dilakukan. Volume pekerjaan yang banyak dan harus diselesaikan sesuai batas waktu yang ditentukan sebelum dilakukan penilaian supervisi pengelolaan laboratorium, maka memerlukan kerja ekstra keras dengan melibatkan rekan guru dan siswa untuk menyelesaikan tugas terstruktur pada siklus 1 dengan pengembangan pekerjaan lain yang bisa diselesaikan, 
sehingga ketika dilakukan penilaian supervisi pengelolaan laboratorium pada akhir tindakan siklus 1, peningkatan nilai rerata pengelolaan laboratorium cukup tinggi.

Sedangkan pada tindakan siklus 2 pelatihan terstruktur dengan diskusi berpasangan dan kunjungan ke laboratorium dan mengerjakan tugas terstrukur pembenahan laboratorium menambah kenaikan nilai rerata pengelolaan laboratorium sebesar 7,50 (10,71\% dari hasil nilai siklus 1 atau 22,22\% dari kondisi awal). Nilai tertinggi pengelolaan laboratorium pada saat kondisi awal sebesar 41,00, kemudian meningkat menjadi 81,00 pada akhir tindakan siklus 1, dan meningkat lagi menjadi 84,00 pada akhir tindakan siklus 2. Secara keseluruhan terdapat peningkatan yang cukup signifikan nilai tertnggi hasil pelatihan terstruktur dari kondisi awal sampai akhir tindakan pada siklus 2 yakni sebesar 43,00.

Relevan dengan kenaikan nilai tertinggi, kenaikan nilai terendah juga cukup tinggi. Pada kondisi awal nilai terendah pengelolaan laboratorium sebesar 29.00 kemudian meningkat cukup tinggi menjadi 67,00 pada akhir tindakan siklus 1, dan meningkat lagi menjadi 71,00 pada akhir tindakan siklus 2. Secara keseluruhan terdapat peningkatan yang cukup signifikan nilai terendah hasil pelaihan terstruktur dari kondisi awal sampai akhir tindakan pada siklus 2 yakni sebesar 42,00.

Rentang nilai pengelolaan laboratorium pada saat kondisi awal sebesar 12,00, kemudian naik menjadi 14,00 pada akhir tindakan siklus 1, dan menurun lagi menjadi 13,00 pada akhir tindakan siklus 2. Gejala naik dan turunnya pengelolaan laboratorium ini disebabkan karena tindakan penelitian ini dilaksanaan bersamaan dengan penyiapan siswa menghadapi ujian nasinal (UN) dan Ujian Sekolah (US) sehingga perubahan rentang nilai sangat dipengaruhi oleh situasi kerja dan kebijakan sekolah saat itu. Kondisi rentang nilai yang demikian menunjukkan bahwa perbedaan kinerja kepala laboratorium berubah-ubah sesuai kondisi sekolah. Perbandingan ketiga kondisi diatas dapat disajikan dalam diagram berikut ini :

Tabel 5 . 
Perbandingan Nilai Pengelolaan Laboratorium pada

Kondisi Awal, Siklus 1, dan Siklus 2

\begin{tabular}{|c|c|c|c|c|c|}
\hline No & Komponen & $\begin{array}{l}\text { Kondisi } \\
\text { Awal }\end{array}$ & $\begin{array}{c}\text { Siklus } \\
1\end{array}$ & $\begin{array}{c}\text { Siklus } \\
\text { 1I }\end{array}$ & $\begin{array}{c}\text { Refleksi dari kondisi awal ke } \\
\text { kondisi akhir }\end{array}$ \\
\hline 1. & Nilai R & 75 & 70,00 & 77,50 & $\begin{array}{l}\text { Terjadi peningkatan nilai rerata } \\
\text { sebesar } 43,50\end{array}$ \\
\hline 2. & $\begin{array}{l}\text { Nilai } \\
\text { Tertinggi }\end{array}$ & 41,00 & 81,00 & 84,00 & $\begin{array}{l}\text { Terjadi peningkatan nilai tertinggi } \\
\text { sebesar } 43,00\end{array}$ \\
\hline 3. & $\begin{array}{l}\text { Nilai } \\
\text { Terendah }\end{array}$ & 29,00 & 67,00 & 71,00 & $\begin{array}{l}\text { Terjadi peningkatan nilai terendah } \\
\text { sebesar } 42,00\end{array}$ \\
\hline 4 & $\begin{array}{l}\text { Rentang } \\
\text { Nilai }\end{array}$ & 12,00 & 14,00 & 13,00 & $\begin{array}{l}\text { Terjadi peningkatan ren tang nilai } \\
\text { sebesar } 01,00\end{array}$ \\
\hline
\end{tabular}

Perbandingan nilai kondisi awal, siklus 1 dan siklus 2 dapat pula dideskripsikan dalam gambar 5 berikut ini.

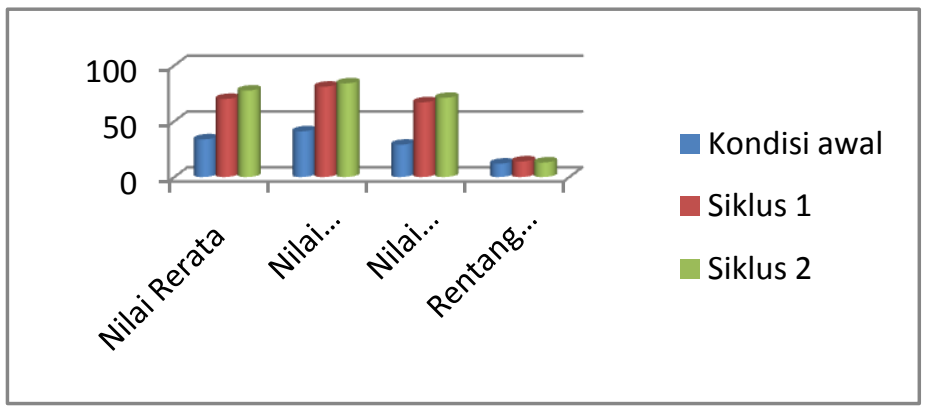

Gambar 2. Diagram Balok Perbandingan Nilai Supervisi Pengelolaan Laboratorium pada Kondisi Awal, Siklus 1, dan Siklus

Peningkatan nilai kinerja kepala laboratorium dan tingkat pengelolaan laboratorium di atas merupakan representasi kontribusi tindakan pelatihan terstruktur terhadap peningkatan kompetensi pengelolaan laboratorium. Hasil penelitian ini sesuai dengan pendapat Armstrong (2004:191) yang menyatakan, "Pelatihan bermanfaat untuk membantu guru mengembangkan keterampilan dan tingkat kemampuan guru" demikian pula Payaman Simanjuntak (2005) yang menyatakan bahwa:"pelatihan merupakan bagian dari investasi SDM (human investment) untuk meningkatkan kemampuan dan keterampilan kerja, ,dan dengan demikian meningkatkan kinerja pegawai". 
Peningkatan perubahan perilaku kepala laboratorium selama mengikuti pelatihan terstruktur dipaparkan dari siklus1 ke siklus 2, hal ini disebabkan karena pada kondisi awal tidak ada proses pelatihan terstruktur sehingga tidak dapat ditangkap dan didiskripsikan kondisi perilaku kepala laboratorium. Berdasarkan hasil deskripsi perilaku ekologis selama pelatihan dapat disajikan hasil deskripsi kondisi perilaku kepala laboratorium pada siklus 1 dan siklus 2 dan peningkatannya seperti tabel berikut:

Tabel 6

Rekapitulasi Deskripsi Peningkatan Perilaku Kepala Laboratorium Selama Proses

\section{Pelatihan Terstruktur}

\begin{tabular}{|c|c|c|c|c|}
\hline \multirow{2}{*}{ No } & \multirow{2}{*}{ Perilaku } & \multicolumn{2}{|c|}{ Perubahan Perilaku } & \multirow[t]{2}{*}{ Sim pulan } \\
\hline & & Siklus 1 & Siklus 2 & \\
\hline 1 & Keaktifan & $\begin{array}{l}\text { Aktivitas peserta cukup, } \\
\text { masih perlu ditingkatkan } \\
\text { antusiasme, semangat dan } \\
\text { respon dalam melakukan } \\
\text { kegiatan }\end{array}$ & $\begin{array}{l}\text { Aktivitas peserta } \\
\text { tinggi, antusias } \\
\text { semangat, dan } \\
\text { cukup respon } \\
\text { dinamika pela tihan lebih } \\
\text { bervariatif }\end{array}$ & $\begin{array}{l}\text { Meningkat dari cukup ke } \\
\text { cukup tinggi }\end{array}$ \\
\hline 2 & Kedisiplinan & $\begin{array}{l}\text { Kedisiplinan } \\
\text { terutama kehadiran dan } \\
\text { ketepatan penyusu nan } \\
\text { tugas }\end{array}$ & $\begin{array}{l}\text { Kedisiplinan mening kat } \\
\text { cukup tinggi dengan } \\
\text { berkurang nya peserta } \\
\text { terlambat dan } \\
\text { meningkatnya ketepat an } \\
\text { penyusunan tugas }\end{array}$ & $\begin{array}{l}\text { Meningkat dari cukup ke } \\
\text { cukup tinggi }\end{array}$ \\
\hline 3 & $\begin{array}{l}\text { Kepercayaan } \\
\text { Diri }\end{array}$ & $\begin{array}{l}\text { Kepercayaan diri kepala } \\
\text { lab. rata-rata cukup, karena } \\
\text { kepercayaan diri senior } \\
\text { lebih tinggi dibandingkan } \\
\text { para yuniornya, terkesan } \\
\text { diskusi dimonopoli para } \\
\text { senior }\end{array}$ & $\begin{array}{l}\text { Kepercayaan diri cukup } \\
\text { tinggi dan lebih merata } \\
\text { karena kesempatan kepada } \\
\text { yunior dibuat lebih besar, } \\
\text { dengan menunjuk maupun } \\
\text { inisiati sediri }\end{array}$ & $\begin{array}{l}\text { Kepercayaan diri } \\
\text { meningkat dari cukup ke } \\
\text { cukup tinggi dan lebih } \\
\text { me rata }\end{array}$ \\
\hline 4 & $\begin{array}{l}\text { Kemampuan } \\
\text { Kerjasama } \\
\text { dan Berbagi }\end{array}$ & $\begin{array}{l}\text { Kemampuan kerjasama } \\
\text { dan berbagi cukup tinggi } \\
\text { dilihat kerjasama saling } \\
\text { berbagi dan bertukar } \\
\text { shoft/hard copy karya/hasil } \\
\text { tugas masing-masing }\end{array}$ & $\begin{array}{l}\text { Kerjasama dan berbagi } \\
\text { meningkat tinggi terbukti } \\
\text { penyelesaian tugas dan } \\
\text { pembenahan laborat } \\
\text { semakin intensif untuk } \\
\text { menghadapi penilaian } \\
\text { akhir pengelolaan } \\
\text { laboratorium }\end{array}$ & $\begin{array}{l}\text { Kerjasama dan berbagi } \\
\text { meningkat dari cukup } \\
\text { tinggi ke tinggi }\end{array}$ \\
\hline
\end{tabular}

Mencermati hasil deskripsi perilaku ekologis pada Tabel 6, menunjukkan bahwa tindakan pelatihan terstruktur mampu meningkatkan semua (empat) perilaku ekologis peserta pada kategori cukup tinggi. Hasil penelitian ini sesuai pendapat Sherman dkk (1988:399) yang menyatakan bahwa " Pelatihan adalah proses yang dimanfaatkan organisasi untuk mengubah perilaku pekerja yang berkontribusi pada keseluruhan misi 
orang dan pengembangan personal dan profesional individu yang terlibat" demikian pula Ivancevich (2008) yang mengatakan, “ Pelatihan (training) adalah sebuah proses sistematis untuk mengubah perilaku kerja seorang/ sekelompok pegawai dalam usaha meningkatkan kinerja organisasi”.

\section{KESIMPULAN}

Berdasarkan penelitian tindakan sekolah ini dapat disimpulkan bahwa terdapat: 1) peningkatan proses pelatihan untuk peningkatan kompetensi kepala laboratorium; 2) peningkatan kompetensi pengelolaan laboratorium melalui pelatihan terstruktur dengan teknik saling berkunjung sebagai berikut peningkatan kinerja sebesar 42,50(117,2\%) dari rerata nilai kinerja 36,25 menjadi 78,75 dan peningkatan pengelolaan laboratorium sebesar 43,50 (128,8\%) dari rerata nilai 33,75 menjadi 77,50; dan (3) perubahan perilaku positif kepala laboratorium dari kategori cukup menjadi cukup tinggi. Peningkatan kompetensi pengelolaaan laboratorium terbukti dapat meningkatkan mutu pengelolaan laboratorium semakin bersih, teratur, tertata, terkelola, teradministrasikan dengan baik dengan suasana lingkungan yang aman dan menyenangkan.

\section{DAFTAR PUSTAKA}

Permendiknas Nomor 26 Tahun 2008 tentang Standar Tenaga Laboratorium Sekolah/Madrasah

Kemendiknas. 2011. Panduan Pelaksanaan Pendidikan Karakter. Balitbang dan Puskur. Jakarta.

Garcia-Barbero, M., 1998. How To Develop Educational Programmes For Health Professionals. Copenhagen, WHO Regional Office for Europe.

Dobson, Graeme, 2003. A Guide to WritingCompetency Based Training Materials. Commonwealth of Australia: Published by National Volunteer Skills Centre.

Permendiknas Nomor 23 Tahun 2006 tentang Standar Kompetensi Lulusan

Peraturan Menteri Pendayagunaan Aparatur Negara Nomor 21 Tahun 2010 sasaran penilaian kinerja kepala laboratorium

Armstrong, Michael, 2004. Performance Management. Tugu. Jogjakarta.

Simanjuntak, Payaman J. 2005. Manajemen dan Evaluasi Kinerja. Jakarta: FE UI. 
Sherman, I. G., \& Sherman, V. G. (1988). The Vertebrates Function an Form. New York: MacMillan Publishing Co. Inc.

Ivancevich, John, M, dkk. 2008. Perilaku dan Manajemen Organisasi, jilid 1 dan 2 Jakarta : Erlangga. 